\title{
A busca da verdade como guia para a trilha filosófica de Agostinho
}

\author{
The search for truth as a guide to the \\ philosophical trail of Augustine
}

Clodoaldo da Luz

Doutorando em Filosofia pela Universidade Federal do Paraná - UFPR

clodoaldoluz@outlook.com

\section{Resumo}

O intento desse artigo é investigar o itinerário filosófico de Agostinho, tendo por base o relato que o próprio Agostinho faz na sua obra Confissões, de sua admiração inicial pela Filosofia, perpassando por sua adesão ao Neoplatonismo, até o seu retiro em Cassicíaco. Levando em consideração que semelhante trajeto agostiniano teve como fito a contemplação da Verdade sobre as bases da Autoridade e da Razão. Nesse sentido, será tecida uma reflexão sobre algumas etapas da vida de Agostinho, do seu primeiro encontro com a Filosofia ao refúgio em Cassicíaco, visando nessa revisitação da caminhada agostiniana perceber que a importância fundamental da Autoridade e da Razão para a busca da Verdade.

Palavras-chave: Verdade. Filosofia. Autoridade. Razão. Agostinho.

\section{Abstract}

The purpose of this article is to investigate the philosophical itinerary of Augustine, based on the account that Augustine himself makes in his work Confessions, of his initial admiration for Philosophy, going through his adherence to Neoplatonism, until his retreat in Cassiciaco. Taking into account that such an Augustinian path was aimed at contemplating the Truth on the basis of Authority and Reason. In this sense, a reflection will be made on some stages of Augustine's life, from his first encounter with Philosophy to the refuge in Cassiciaco, aiming at this revisitation of the Augustinian journey to realize that the fundamental importance of Authority and Reason for the search for Truth.

Keywords: Truth. Philosophy. Authority. Reason. Augustine. 


\section{Considerações iniciais}

A vida e a Filosofia de Agostinho se encontram intrinsecamente entrelaçadas. O seu itinerário existencial desvela sua vontade de contemplar a Verdade e os passos trilhados com esse fim. Semelhante trajetória é esboçada por Agostinho na sua obra Confissões'.

O Hiponense, ao revisitar fatos marcantes de sua vida, quer não somente trazer à luz os seus passos sob a guisa da Filosofia, mas anseia também evidenciar que sua caminhada filosófica pode representar a busca da Verdade que se inscreve em todo homem. Agostinho, ao expor sua caminhada, indica que o homem apesar dos entraves que se apresentam nesse itinerário, é capaz, por intermédio da Filosofia, de satisfazer tal anseio.

Considerando isso, torna-se oportuno uma reflexão sobre sua caminhada filosófica e seu desejo de contemplar a Verdade - tendo em vista a interação entre a Autoridade das Escrituras e a Razão. Nesse intuito, serão apresentados e refletidos os passos concedidos por Agostinho, do seu vislumbre pela Filosofia até a sua decisão de refugiar-se com os seus amigos e familiares em Cassicíaco, tendo em mente que o afã de contemplar a Verdade fora o norte de seu itinerário filosófico.

\section{Do encantamento pela filosofia ao ingresso no maniqueísmo}

O encontro marcante do Hiponense com a Filosofia ocorreu, provavelmente, no ano de 373 d. C., em Cartago. Agostinho, então com 19 anos, no curso de formação em oratória, pôde, mediante o conteúdo programático desse curso, ter a possibilidade de ler a obra Hortênsio de Cícero:

Seguindo o programa normal do curso, chegou-me às mãos o livro de um tal Cícero, cuja linguagem - mas não o coração - é quase

\footnotetext{
${ }^{1}$ Livro no qual Agostinho revisita momentos importantes de sua vida. Ele o faz como se fosse uma confissão de seus anseios, realizações, quedas, recomeços, fragilidades. Mas, acima de tudo, explana o ideal de contemplar a Verdade (Cf. MATTHEWS, 2007, p. 17-27).
} 
unanimente admirada. O livro é uma exortação à filosofia e chamase Hortênsio. Devo dizer-me que ele mudou os meus sentimentos e o modo de me dirigir a ti; ele transformou minhas aspirações e desejos (AGOSTINHO, 1984, p. 63, grifos do autor).

Tal evento marcou profundamente a vida de Agostinho. O encantamento pela Filosofia, advindo da leitura da obra ciceroniana Hortênsio, o impulsionou para o propósito de contemplar a Verdade: "Atraía-me aquela exortação, pelo fato de não me excitarem a amar, buscar, seguir, abraçar com ardor essa ou aquela seita, mas simplesmente a sabedoria, qualquer que fosse" (Ibid., p. 64).

Nesse escopo, Agostinho se volta às Escrituras. Semelhante ato do Hiponense pode suscitar a questão: se em Agostinho o ímpeto de buscar a Sabedoria fora despertado pela mediação da leitura filosófica de Cícero, por que em seguida dirigir-se às Escrituras e não se debruçar na literatura filosófica? Uma possível solução a essa indagação é trazida por Brown:

A forma exata de 'Sabedoria' que ele iria buscar difereria muito, é claro, do que Cícero reconheceria como tal. Agostinho vinha de uma família cristã. Numa era da qual foram preservados apenas textos de adultos, é extremamente difícil apreender a natureza do cristianismo 'residual' de um jovem. Mas uma coisa é certa: um saber pagão sem 'o nome de Cristo' estava totalmente fora de cogitação (2005, p. 50).

Após a fascinação pela Filosofia, o passo seguinte no itinerário agostiniano de contemplação da Verdade era a busca dela através da Autoridade que ele supunha haver nas Escrituras. Assim, Agostinho pretendia realizar através das Escrituras o programa de Hortênsio: a contemplação da Verdade.

Para a decepção do Hiponense, o que ele viu na leitura das Escrituras era aquém do estilo com o qual ele tivera contato na Filosofia de Cícero, através do Hortênsio:

Resolvi por isso dedicar-me ao estudo das Sagradas Escrituras, para conhecê-las. E encontrei um livro que não se abre aos soberbos e que também não se revela às crianças; humilde no começo, mas que nos leva aos píncaros e está envolto em mistério, à medida que se vai à frente. Eu era incapaz de nele penetrar ou de baixar a cabeça à sua entrada. $O$ que senti nessa época, diante das Escrituras, foi bem diferente do que agora afirmo. Tive a impressão de uma obra indigna de ser comparada à majestade de Cícero. Meu orgulho não podia suportar aquela simplicidade de estilo. Por outro lado, a agudeza de minha inteligência não 
conseguia penetrar-lhe o íntimo. Tal obra foi feita para acompanhar o crescimento dos pequenos, mas eu desdenhava fazer-me pequeno, e, no meu orgulho, sentia-me grande (Ibid., p. 65).

Segundo o parecer de Agostinho, as Escrituras se mostraram ínfimas, pequenas e simplórias perante a eloquência da referida obra filosófica de Cícero. Nesse sentido, a comparação que o Hiponense fez de ambas evidencia, aos seus olhos, uma suposta simplicidade das Escrituras. Mas, sendo ela revestida de Autoridade, como pensava Agostinho, por que o Hiponense se frustrou ao lê-la? 0 seguinte excerto de Brown ajuda a ver a possível causa que o levou a repensar sua consideração sobre as Escrituras frente ao Hortênsio de Cícero:

Foi uma grande decepção. Ele fora criado na expectativa de que os livros fossem 'cultos e burilados'; recebera uma formação criteriosa para se comunicar com homens instruídos da única maneira admissível: num latim escrupulosamente moldado nos autores da Antiguidade. Para um homem desse feitio, o linguajar coloquial e os dialetos incompreensíveis eram igualmente abomináveis; e a Bíblia latina da África traduzida séculos antes por autores humildes e anônimos, estava repleta de ambos. E mais, o que Agostinho leu na Bíblia parecia ter pouco a ver com a Sabedoria altamente espiritual que Cícero lhe dissera para amar (2005, p. 51).

O grande obstáculo entre a escrita de Cícero e as Escrituras era uma questão de forma estilística e não de conteúdo. Ademais, os fatos narrados no Antigo Testamento eram obscuros ao Hiponense, pois haviam vários relatos de infanticídio, de parricídio, de adultério, de concubinato, etc., os quais aparentemente divergiam da mensagem do Cristo que se fazia presente no Novo Testamento.

Frustrado com a Autoridade das Escrituras, mediante a grande incidência dos episódios citados acima, Agostinho provavelmente de 374 d. C. a 383 d. C. adere ao Maniqueísmo ${ }^{2}$. O ingresso na seita maniqueia marcou profundamente a juventude do Hiponense. Um jovem sagaz que visava satisfazer o seu intento de percorrer a trilha filosófica, com o desejo de contemplar a Verdade.

\footnotetext{
${ }^{2}$ Era uma seita religiosa filosófica dualista, fundada no século III d. C. por Mani, que se considerava o fidedigno seguidor de Cristo. Pressuponha que havia uma luta cósmica entre o bem e o mal (Cf. ABBAGNANO, 2007, p.739).
} 


\section{Da adesão ao Maniqueísmo ao período 'cético' de Agostinho}

Durante nove anos, por volta de 374 d. C. a 383 d. C., ainda no período de formação de retórico em Cartago até seu retorno a Tagaste, sua terra natal, Agostinho, dos 19 aos 28 anos de idade, adere ao Maniqueísmo. "Caí assim nas mãos de homens desvairados pela presunção, extremamente carnais e loquazes: [...] Repetiam: Verdade! Verdade" (AGOSTINHO, 1984, p. 65-66).

Esse período maniqueísta de sua vida é assim apresentado pelo Hiponense:

Durante os nove anos que se seguiram, dos dezenove aos vinte e oito anos de idade, fui muitas vezes seduzido e sedutor, enganado e enganador, em meio às diversas paixões, ensinando, de público, as ciências chamadas liberais e, em particular, praticando uma religião indigna de tal nome. Ora soberbo, ora supersticioso, sempre vaidoso. Ora em busca do quimérico louvor popular - até mesmo de aplauso no teatro - e dos concursos de poesia, das disputas de coroas de feno, de espetáculos frívolos e do desregramento das paixões (Ibid., p. 81).

É perceptível pelo excerto acima que tal período de sua vida fora um tanto quanto conturbado. Certamente muitos questionamentos instavam respostas. No Maniqueísmo, Agostinho buscava soluções para suas indagações.

As principais questões que afligiam Agostinho e o fizeram adentrar na fileira maniqueísta foram os problemas do mal e da natureza de Deus:

Eu ignorava a outra realidade, a verdadeira, e era levado a aceitar o que me parecia o penetrante raciocínio de estúpidos impostores, quando me faziam perguntas sobre a origem do mal, se Deus se circunscreve a uma forma corpórea, se tem unhas e cabelos (Ibid., p. 68).

No maniqueísmo, Agostinho poderia, a seu ver, encontrar resposta para as questões que o atormentavam. Além do anseio por responder a essas indagações, quais especificidades do maniqueísmo o levaram a se engajar nessa seita? Uma possível resposta se evidencia no plano filosófico, pois os maniqueus

prometiam uma interpretação das Escrituras que era satisfatória para a razão e que fazia apelo à fé, somente na medida exata em que a razão fosse capaz de justificá-la, o que agradava ao jovem 
leitor do Hortensius. O problema era encontrar uma sabedoria filosófica nas Escrituras, e isso é precisamente o que os maniqueus prometiam (GILSON, 2006, p. 435, grifos do autor).

Dessa forma, frustrado com a Autoridade das Escrituras, Agostinho visa, através da explicação racional disponibilizada pelo Maniqueísmo, contemplar a Verdade. Também na seita maniqueia, o Hiponense poderia dar vazão à sua inclinação religiosa:

Agostinho frequentou os conventículos dos maniqueístas para ouvir a grande 'Carta de fundação' de Mani. Nessa ocasião solene, os 'ouvintes' eram 'enchidos de luz'. Essa 'iluminação' era a experiência religiosa inicial e básica de um maniqueu: era um homem que se haveria tornado cônscio de sua condição (BROWN, 2005, p. 58).

E como Agostinho, os maniqueus também tinham ressalvas em relação ao Antigo Testamento: "No maniqueísmo, o severo Jeová dos judeus era rejeitado como um demônio maléfico, e os patriarcas, como velhos sórdidos... 'eu sabia, sabia que sempre odiastes essa história', escreveria um maniqueísta a Agostinho, tempos depois" (Ibid., p. 61).

Nas Confissões, o Hiponense confirma a aversão maniqueia às personagens do Antigo Testamento:

Desconhecia a verdadeira justiça interior que não julga pelos costumes, mas pela retíssima lei de Deus onipotente, com a qual se devem conformar os costumes das nações e dos tempos; ela permanece a mesma sempre e em qualquer lugar, sem se alterar, enquanto mudam as nações e os tempos. De acordo com essa lei, viveram na justiça Abraão, Isaac, Jacó, Moisés, Davi e todos os outros que Deus louvou por sua própria boca. Os ignorantes, porém, que julgam conforme a sabedoria humana, os consideram injustos (AGOSTINHO, 1984, p. 69).

$\mathrm{Na}$ condição de maniqueísta, Agostinho não conseguira professar o cristianismo, pautando-se na Razão porque somente acreditaria naquilo que a racionalidade pudesse explicar. Assim, as passagens extravagantes das Escrituras, sobretudo as do Antigo Testamento, não teriam importância alguma. Tal ênfase na Razão como norte para contemplar a Verdade, num primeiro momento, satisfez as inquietações de Agostinho. 
A carreira do jovem maniqueísta de 22 anos, agora professor de retórica em Cartago, provavelmente no ano de 376 d. C., estava em franca ascensão. No limiar da promissora docência, Agostinho escreve sua primeira obra De pulchro et apto ${ }^{3}$ :

Ignorando tudo isso, eu amava as belezas terrenas e caminhava para o abismo, dizendo aos meus amigos: Amamos por acaso algo que não seja o belo? E o que é o belo, o que é a beleza? O que é que nos atrai e nos liga aos objetos que amamos? Se não tivessem harmonia e encanto, não seríamos atraídos. Eu via e observava, então, que, num corpo, uma coisa é a beleza no seu todo, e outra é a sua sintonização com os outros corpos, e isso é a harmonia, tal como a parte em relação ao todo, o calçado em relação ao pé, e coisas semelhantes. Essa consideração brotou-me no espírito, do fundo do coração, e por isso escrevi alguns livros, não sei se dois ou três, sobre a beleza e a harmonia. Sabes, ó Deus, porque os esqueci e não mais os possuo. Eles me desapareceram, não sei como (Ibid., p. 96).

Apesar do êxito profissional, os questionamentos advindos pela participação na seita maniqueia se intensificaram na cabeça do Hiponense: a substância divina seria espiritual ou corporal? E o mal, qual seria a sua substância? Seria ele um ser? As soluções maniqueias, no que tange semelhantes questionamentos, foram apenas paliativas ao Hiponense.

Desse modo, Agostinho se via em diversos questionamentos:

Parecia-me realmente indigno acreditar que havias tomado a imagem humana e circunscrito tua divindade nos limites de um corpo humano. E, no entanto, quando queria pensar no meu Deus, só sabia representá-lo sob a forma de massa corpórea. (Parecia-me que não devia existir nada de incorpóreo). E esta era a principal e, talvez, a causa única do meu erro. Em consequência, eu deduzia que também o mal era uma substância desse gênero, ora massa escura e disforme, ora espessa, chamada terra, ora tênue e sutil, como o ar, que os maniqueus imaginavam como um espírito maligno rastejando sobre a terra. Mas, certa religiosidade que possuía me obrigava a crer que um deus bom não podia ter criado uma natureza má. Concluía daí que devia haver duas substâncias opostas entre si, ambas infinitas, sendo, porém, a má em medida mais limitada, e a boa em medida mais ampla (Ibid., p. 122).

\footnotetext{
${ }^{3}$ Do belo e do capaz foi a primeira obra escrita por Agostinho, por volta de seus 22 anos de idade, em 376 d. C. É uma obra que se perdera. Ao que tudo indica o conteúdo desse livro versa sobre a estética e a filosofia clássicas (Cf. MATTHEWS, 2007, p. 30).
} 
Além desses questionamentos, advindos da explicação racional das Escrituras e da realidade defendida na seita maniqueia, o Hiponense não aceitava as doutrinas astrológicas defendidas no Maniqueísmo:

Os livros desta seita, na verdade, estão cheios de intermináveis fantasias a respeito do céu, dos astros, do sol e da lua. Na verdade, eu já não esperava que ele pudesse mostrar de modo satisfatório, - que eu mais desejava saber: se essas dificuldades eram resolvidas mais claramente nos livros maniqueístas ou naqueles em que eu havia encontrado cálculos que me satisfaziam, ou se pelo menos as duas soluções se equivaliam (Ibid., p.115).

O momento decisivo do rompimento com o Maniqueísmo ocorreu no encontro com o bispo Fausto, grande personagem maniqueu:

Durante cerca de nove anos, em que meu pensamento errante escutava a doutrina maniqueísta, aguardava ansiosamente a chegada desse Fausto. Todos os outros maniqueus, com quem tivera ocasionalmente contato, não sabiam responder às objeções que eu lhes apresentava, e me prometiam que, à chegada dele, e num simples colóquio, seriam resolvidas, com extrema facilidade, essas e outras questões ainda mais graves que eu viesse a propor. Assim, quando ele chegou, travei conhecimento com um homem amável, de fala agradável, capaz de expor de forma muito mais atraente o que os outros dizem. Mas que importavam à minha sede os preciosos cálices de um copeiro? Meus ouvidos já estavam saturados de semelhantes discursos; não me pareciam melhores porque feitos em linguagem mais burilada, ou mais verdadeiros por serem mais eloquentes. Nem me parecia ele mais sábio pelo fato de ter aspecto simpático e falar elegante. $E$ aqueles que o haviam elogiado não eram bons conhecedores da realidade, pois o tinham na conta de prudente e sábio por se agradarem de sua eloquência. [...] Depois que me pareceu evidente ser aquele homem incompetente nas ciências em que o considerara competentíssimo, comecei a desesperar de sua capacidade para explicar e resolver os problemas que me angustiavam (/bid., p. 113-114.115).

Novamente, Agostinho se vê frustrado na sua busca pela Verdade. Se, outrora, a aparente simplicidade das Escrituras dissipou a Autoridade que Agostinho pressuponha haver nelas; agora, a concepção maniqueia, pautada na Razão, não conseguia solucionar as suas questões. Ora, se nem a Autoridade e nem a Razão possibilitariam ao homem contemplar a Verdade, essa seria inalcançável a ele. Portanto, em meio às desilusões com a Autoridade e com a Razão na busca da Verdade, Agostinho passa a considerar que a postura cética acadêmica, que ele 
conhecera através da obra ciceroniana Acadêmicas, fosse a mais adequada em relação à possibilidade do conhecimento: "Viera-me de fato a ideia de que os mais esclarecidos entre os filósofos eram os chamados Acadêmicos, quando afirmavam ser preciso duvidar de tudo, e que o homem nada pode compreender da verdade" (Ibid., p. 122).

Perante a ineficácia, a seu ver, da Autoridade das Escrituras e da Razão, advogada pela seita maniqueia, o Hiponense adentra num período de mais intenso e contínuo questionamento.

Tal período da vida do Hiponense é fecundo para a compreensão de seu projeto de oposição ao posicionamento epistemológico acadêmico, por ser uma etapa na qual a esperança de contemplar a Verdade não desapareceu, pelo contrário, se transformou numa procura mais cuidadosa.

\section{Da aceitação da postura cética acadêmica à leitura alegórica das Escrituras}

A percepção de que a contemplação da Verdade por meio da Autoridade e da Razão se fazia impossível pontuou essa fase da vida do Hiponense e a qual é relatada por Agostinho no seu diálogo $A$ Vida Feliz" : "Enfim, após ter discutido com eles, abandonei-os. Tendo percorrido aquele mar por muito tempo, entreguei em seguida o timão do meu barco aos acadêmicos. Foi ele então sacudido por toda espécie de ventos, em meio a vagalhões" (AGOSTINHO, 1998, p. 120).

Esse período de Agostinho, que vai possivelmente de 383 d. C. a 385 d. C., é resumido, nas Confissões, por ele dessa forma:

Ó minha esperança desde a minha juventude, onde estavas, para onde te retirastes? Não fostes tu que me criastes e me quisestes diferente dos animais, mais inteligente que as aves do céu? $\mathrm{E}$, no entanto, eu caminhava em meio às trevas e por terrenos escorregadios. Eu te buscava fora de mim, e não encontrava o Deus do meu coração. Havia chegado ao fundo do mar, e não tinha mais

\footnotetext{
${ }^{4}$ Nesse livro Agostinho na comemoração do seu trigésimo segundo aniversário, reunido com sua mãe, familiares e convivas, faz uma breve recapitulação de momentos importantes de sua vida. À luz de sua obra posterior Confissões, esse resgate biográfico de Agostinho na Vida Feliz pode ser apontado como 'breves confissões' (Cf. AGOSTINHO, 1998, p. 120-122).
} 
confiança nem esperança de encontrar a verdade (AGOSTINHO, 1984 , p. 131 , grifos do autor).

A influência desse período 'cético' de Agostinho, que vai possivelmente de 383 d. C. a 385 d. C., fora determinante na sua trilha filosófica. Mas de que forma semelhante influência se posicionou frente ao seu ímpeto de contemplar a Verdade? Com o propósito de refletir essa questão é importante vermos as considerações que Dutton e Kenny tecem sobre essa etapa da vida de Agostinho. O primeiro considera que esse período da vida do Hiponense, devido às incessantes dúvidas que lhe afligiam, pode ser considerado como uma crise cética (Cf. DUTTON, 2016, p. 13). Essa afirmação de Dutton faz transparecer um total abandono da busca da Verdade que Agostinho tinha objetivado. Já Kenny descreve esse momento dúbio do Hiponense como um período no qual os elementos da postura cética acadêmica tivessem Ihe oferecido um subsídio epistemológico, que servira ao Hiponense no seu escopo. Isto porque, possivelmente, Agostinho, ao ter conhecido tal posicionamento epistemológico, teria sido mais prudente ao conceder prontamente o seu assentimento a uma nova matriz filosófica. Assim, o Hiponense teria utilizado os argumentos céticos da Nova Academia (Cf. KENNY, 2005, p. 156).

Aparentemente, a asserção de Dutton é razoável, pois, conforme o próprio Hiponense dissera, as esperanças de contemplar a Verdade tinham desaparecido.

Contudo, a proposição de Kenny, conforme se verá, é a que melhor refletirá esse período da vida de Agostinho, pois segundo o Hiponense:

Ouvindo agora a explicação espiritual de tais passagens, eu me reprovava a mim mesmo por ter acreditado que as Lei e os Profetas não pudessem resistir aos ataques e insultos de seus inimigos. Todavia, não me sentia no dever de abraçar a fé católica só pelo fato de que ela podia contar com doutos defensores, capazes de refutar as objeções dos adversários com argumentos sérios. Por outro lado, não me pareciam condenáveis as doutrinas que abraçara: os argumentos de defesa das duas partes equivaliam-se. A fé católica não me parecia vencida, mas para mim ainda não se afigurava vencedora. Foi então que comecei a empenhar todas as forças do espírito na busca de um argumento decisivo para demonstrar a falsidade dos maniqueus. Se me fosse possível conceber uma substância espiritual, todos os obstáculos teriam sido superados e afastados do meu espírito. Mas não podia. Contudo, em relação à própria estrutura do mundo e à natureza inteira e perceptível a nossos sentidos físicos, minhas reflexões e comparações me convenciam cada vez mais de que a maior parte 
dos filósofos tinha opiniões bem aceitáveis. Assim, duvidando de tudo, à maneira dos acadêmicos - como se imagina comumente flutuando entre todas as doutrinas, resolvi abandonar os maniqueus (AGOSTINHO, 1984, p. 125-126).

Ademais, o Hiponense, pela influência do mesmo Cícero, não perdera de vista a possibilidade, mesmo que remota, de contemplar a Verdade: "Esse período comparativamente curto de incerteza foi um dos momentos decisivos mais cruciais e menos conhecidos de sua vida, porque o fez compreender com clareza o ideal da 'Sabedoria' como uma busca prolongada. Cícero nunca havia abandonado esse ideal" (BROWN, 2005, p. 95).

Por mais que tal 'período acadêmico' do Hiponense, ocasionado pelas frustrações perante a Autoridade das Escrituras e da explicação racional maniqueia, tenha lhe incitado a questionar se a Verdade é acessível ao homem, Agostinho não perdera de vista o seu objetivo de contemplar a Verdade. Sob esse prisma, o substrato intelectual obtido nesse momento de sua vida fora importante para a continuação do seu intento.

A mudança de Cartago para Roma, possivelmente em 383 d. C., depois para Milão, por volta de 384 d. C., ocasionou três fatos importantes em sua vida, que o fizeram repensar sua admiração pela postura cética da Academia e resolver duas questões pontuais, isto é, se Deus é um ser corpóreo e qual a origem e natureza do mal: a oportunidade de ouvir os sermões de Ambrósio, a descoberta dos livros neoplatônicos e um renovado estudo da Escritura (Cf. DUTTON, 2016, p. 14).

Primeiramente, Agostinho, em Milão, pode conhecer Ambrósio, bispo de Milão:

Assim que cheguei a Milão, encontrei o bispo Ambrósio, conhecido no mundo inteiro como um dos melhores, e teu fiel servidor. Suas palavras ministravam constantemente ao povo a substância do teu trigo, a alegria do teu óleo e a embriaguez sóbria do teu vinho. Tu me conduzias a ele sem que eu o soubesse, para que eu fosse por ele conduzido conscientemente a ti. Esse homem de Deus acolheume paternalmente e ficou feliz com a minha chegada, na bondade digna de um bispo. Comecei a estimá-lo, a princípio não como mestre da verdade, pois não tinha a esperança de encontrá-la em tua Igreja, mas como homem bondoso para comigo (AGOSTINHO, 1984, p. 125). 
Após um longo tempo ouvindo as locuções de Ambrósio, Agostinho, por volta de 385 d. C., teve contato com um novo modo de ler e refletir sobre as Escrituras - a leitura alegórica:

\begin{abstract}
Alegrava-me, também, por ter aprendido a ler as antigas Escrituras da Lei e dos Profetas, com a interpretação diferente daquelas que antes me pareciam absurdas, quando eu acusava teus santos de terem fé em coisas nas quais realmente não acreditavam. Alegravame ouvir Ambrósio quando, muitas vezes em seus sermões, recomendava ao povo a norma a ser escrupulosamente observada: a letra mata, mas o espírito comunica a vida. Removido assim o místico véu, esclareceram-se espiritualmente passagens que, tomadas ao pé da letra, pareciam ensinar o mal. Nada ele dizia que eu não pudesse aceitar, embora ainda não estivesse certo de que as palavras dele eram verdadeiras (Ibid., p. 136, grifos do autor).
\end{abstract}

Tal fato é de suma importância, pois além de mostrar a influência de Ambrósio sobre Agostinho, por intermédio da leitura simbólica das Escrituras, o Hiponense teria resolvido a sua primeira dificuldade: a sua interpretação das Escrituras. A primeira dificuldade de Agostinho foi resolvida pela leitura simbólica das Escrituras de Ambrósio (Cf. MENN, 1998, p. 75). Aliás, Agostinho compreendeu que as Escrituras não devem ser entendidas de modo literal, e sim de forma simbólica; e o fez pensar na importância da crença e da Autoridade, para a devida reflexão racional.

Destarte, Agostinho, à maneira dos Acadêmicos, questiona se é necessário seguir alguma Autoridade em seu agir, sobretudo a das Escrituras. Partindo desse arrazoado, passa a considerar que se não aceitasse nenhuma Autoridade, não se poderia fazer nada. Assim, paulatinamente, o Hiponense passa a ter certeza de que uma vida sem crença é impossível. Para que se possa agir, necessariamente se deve, como primeiro passo, acreditar no testemunho de terceiros. Com base nisso, avalia que se é plausível aceitar fatos não vistos e opiniões de quem não se conhece, também é razoável acreditar na Autoridade das Escrituras:

E enquanto tua mão suave e misericordiosa plasmava e formava pouco a pouco o meu coração, eu refletia na intimidade de fatos em que acreditava, sem tê-los visto ou deles ter sido testemunha. Assim, os muitos episódios da história da humanidade, a existência de lugares e cidades nunca visitados, conhecimentos recebidos de amigos, de médicos e de tantos outros em quem temos de acreditar, sob pena de nada podermos realizar na vida. Enfim, como estava absolutamente seguro da identidade de meus pais, o que 
não poderia saber sem acreditar no que ouvia. Convenci-me então de que, longe de repreender os que acreditam em tuas Escrituras, reconhecidas com tanta autoridade em quase todos os povos, são repreensíveis aqueles que não acreditam e a quem não se deve dar ouvidos se disserem: Como sabes que estes livros foram dados aos homens pelo espírito do único Deus, que é a verdade? E isso se adequava tanto melhor à minha crença, quanto é certo que nenhum argumento, por mais capcioso que fosse, de tantos filósofos que discordavam entre si, cujos livros estudei, tinha podido arrancar do meu coração a fé na tua existência, apesar de ignorar o que eras e desconhecer que o governo das coisas humanas pertence a ti (AGOSTINHO, 1984, p. 137-138).

Desse modo, ciente da importância da Autoridade, o Hiponense chega à consideração de que a Razão desprovida da Autoridade não seria, por si só, capaz de levar o homem à Verdade:

Mas sempre acreditei que existes e que cuidas de nós, embora não soubesse que ideia devesse ter de tua natureza, ou que caminho nos levaria ou reconduziria a ti. Portanto, sendo os homens incapazes de encontrar a verdade mediante a razão pura, e tendo necessidade do apoio das Sagradas Escrituras, eu já principiava a crer que não concederias tanta autoridade por toda a terra a estes Livros Sagrados se não estivesse querido que se acreditasse em ti e se buscasse a ti através deles (/bid., p. 138).

A partir desse momento, Agostinho reconsidera sua apreciação em relação à postura cética acadêmica e, assim, encerra-se o seu 'período cético'. Conforme visto, a influência de Ambrósio fizera o Hiponense, por intermédio da leitura alegórica das Escrituras, pensar que é racional aceitar e dar assentimento à Autoridade das Escrituras.

Em posse de um novo modo de compreensão e leitura das Escrituras, através da audição das homilias e sermões de Ambrósio, Agostinho considera que é necessário crer para que se possa compreender. Ele mesmo afirma isso, posteriormente, no Livre-Arbitrio": "Com efeito, se crer não fosse uma coisa e compreender outra, e se não devêssemos, primeiramente, crer nas sublimes e divinas verdades que desejamos compreender, seria em vão que o profeta teria dito: 'Se não o crerdes não entendereis' (Is7, 9, na LXX)" (AGOSTINHO, 1995, p. 78-79).

\footnotetext{
${ }^{5}$ Obra de Agostinho iniciada em 388 d. C. e terminada em 394 d. C. Nela o Hiponense dialoga com seu amigo Evódio sobre as questões da liberdade humana e da origem do mal moral (Cf. OLIVEIRA, 1995, p. 11-13).
} 
Nesse sentido, as questões da acessibilidade do conhecimento ao homem e a supressão total do assentimento, que eram pontos importantes da postura cética acadêmica, caíram por terra.

\section{Leitura dos livros neoplatônicos e resolução de duas questões pontuais}

Mesmo tendo suplantado o pessimismo de encontrar a Verdade, havia duas questões que ainda afligiam Agostinho.

Uma era a corporeidade de Deus:

Não te concebia, ó meu Deus, sob a forma de corpo humano, pois já começara a escutar a verdadeira sabedoria. Aliás, eu sempre fugira desse conceito e me sentia feliz de encontrar na doutrina de nossa mãe espiritual, a santa Igreja católica, aquilo que no fundo eu sempre havia pensado. Mas não me ocorria outra forma de conceber-te (AGOSTINHO, 1984, p. 159).

Outra é a origem do mal: "Desse modo, ó meu Socorro, tu me havias libertado dessas cadeias. Eu, porém, continuava a procurar a origem do mal, e não encontrava resposta" (Ibid., p. 169).

Por volta do ano de 386 d. C. ocorreu um episódio de suma importância para Agostinho: a leitura dos livros neoplatônicos ${ }^{6}$, provavelmente as obras de Plotino e/ou de Porfírio de Tiro, as quais foram traduzidos do grego para o latim por Mário Vitorino:

Quisestes mostrar-me, antes de tudo, como fazes resistência aos soberbos e concedes a tua graças aos humildes, e como em tua misericórdia quisestes indicar o caminho da humildade, visto que o teu Verbo se fez carne e habitou entre os homens. Tu me proporcionaste, através de um homem inflado de orgulho imenso alguns livros dos platônicos, traduzidos do grego para o latim (Ibid., p. 171-172).

\footnotetext{
${ }^{6} \mathrm{Na}$ sua obra Confissões Agostinho apresenta esses livros como sendo de autoria de filósofos platônicos. Todavia, a hipótese mais aceita é de que estes livros são de Plotino e Porfírio, filósofos neoplatônicos (Cf. AGOSTINHO, 2002, p. 22). Porém, a hipótese mais aceita é de que estes livros são de Plotino e Porfírio, filósofos neoplatônicos (Cf. HENRY, 1934, p. 69-70).
} 
Por intermédio da leitura e reflexão neoplatônica, o Hiponense enfim pôde conceber uma realidade inteligível, isto é, Deus enquanto ser espiritual:

Instigados por esses escritos a retornar a mim mesmo, entrei no íntimo do meu coração sob a tua guia, e o consegui, porque tu te fizeste meu auxílio. Entrei e, com os olhos da alma, acima destes meus olhos e acima de minha própria inteligência, vi uma luz imutável. Não era essa luz vulgar e evidente a todos com os olhos da carne, ou uma luz mais forte do mesmo gênero. Era como se brilhasse muito mais clara e tudo abrangesse com sua grandeza. Não era uma luz como esta, mas totalmente diferente das luzes desta terra. Também não estava acima de minha mente como o óleo sobre a água nem como o céu sobre a terra, mas acima de mim porque ela me fez, e eu abaixo porque fui feito por ela. Quem conhece a verdade conhece esta luz, e quem a conhece, conhece a eternidade. $\mathrm{O}$ amor a conhece. Ó eterna verdade, verdadeira caridade e querida eternidade! És o meu Deus, por ti suspiro dia e noite (Ibid., p. 175, grifos do autor).

Deste modo, agora o Hiponense tem acesso a um novo horizonte filosófico, através do qual ele integra o seu esforço de contemplar a Verdade: "Depois de ter lido os livros platônicos, que me estimularam a procurar a verdade incorpórea, aprendi a descobrir teus atributos invisíveis através das coisas criadas" (/bid., p. 183-184).

Partindo da matriz filosófica neoplatônica, Agostinho pode orientar sua reflexão: partindo do sensível até a transcendência do inteligível:

Eu procurava os motivos pelos quais apreciava a beleza dos corpos, quer celestes, quer terrenos, e a razão dos juízos que com equidade eu fazia sobre os seres mutáveis quando dizia comigo mesmo: Isto está bem assim, aquilo não. E procurando descobrir, em que me baseava para julgar dessa maneira, acima de minha inteligência mutável, a verdade autêntica, a eternidade imutável. Desse modo, elevei-me gradualmente do corpo até a alma, a qual sente por meio do corpo e da alma até sua força interior, à qual os sentidos comunicam a realidade exterior, e que é o limite atingido pelas faculdades dos animais. Daí subi até o poder de raciocínio, que julga conforme a percepção fornecida pelos sentidos corporais. Mas, como também essa potência se reconhece mutável, elevou-se até a inteligência e, afastando o pensamento de suas cogitações habituais, desembaraçou-se do turbilhão de fantasias contraditórias, descobrindo então qual a luz que lhe iluminava a inteligência ao afirmar com segurança que o imutável é preferível ao mutável. Por conseguinte, daí vinha a ela o próprio conceito de imutabilidade, conceito esse que de algum modo a inteligência 
devia possuir para que pudesse preferi-lo ao que é mutável. Foi assim que, num lampejo de comovida intuição, ela chegou até aquele que é (Ibid., p.180-181).

Também fora capaz de conceber que o mal não é um ser, mas sim uma privação. Sua origem decorre disto:

\begin{abstract}
Vi claramente que as coisas corruptíveis são boas. Não se poderiam corromper se fossem sumamente boas, ou se não fossem boas. Se fossem absolutamente boas, não seriam corruptíveis. $E$ se não fossem boas, nada haveria a corromper. A corrupção de fato é um mal, porém, não seria nociva se não diminuísse um bem real. Portanto, ou a corrupção não é um mal, o que é impossível, ou - e isto é certo - tudo aquilo que se corrompe sofre uma diminuição de bem. Mas privadas de todo bem, deixaria inteiramente de existir sem que pudessem corromper-se, seriam melhores, porque permaneceriam incorruptíveis. Mas haverá maior absurdo do que afirmar que as coisas se tornariam melhores perdendo todo o bem? Portanto, se são privadas de todo o bem, deixarão totalmente de existir. Logo, enquanto existem, são boas. Portanto, todas as coisas, pelo fato de existirem são boas. E aquele mal cuja origem eu procurava, não é uma substância. Porque, se o fosse, seria um bem (/bid., p. 177).
\end{abstract}

Em posse de uma nova concepção filosófica, Agostinho revisita as Escrituras. Uma possível explicação para isto pode estar na concepção agostiniana, que a Autoridade e a Razão são as duas vias para o conhecimento. Além do que, conforme visto, para Agostinho é necessário que primeiro se creia para depois compreender. Mas, além disso, teria alguma outra motivação? A essa questão Brown oferece a seguinte informação histórica:

Em Milão, grande parte do platonismo desenvolto e elegante era cristão. Essa mudança, sumamente significativa, tivera início em Roma, em meados do século. Ali, um professor africano de retórica, Mário Vitorino, ligara-se subitamente à Igreja cristã. Havia traduzido Plotino e outros escritos neoplatônicos para o latim (2005, p. 111).

Já no âmbito filosófico, a existência em Milão de um grupo de cristãos, incluindo Ambrósio, que foi fortemente influenciado pelo pensamento neoplatônico propiciou ao Hiponense o contato com os escritos de Plotino e possivelmente de Porfírio. Tais obras permitiram-lhe conceber Deus e a alma como realidades não 
corporais e, ao menos, em grande medida, forneceram soluções para suas dificuldades intelectuais com o cristianismo (Cf. TESKE, 2009, p. 21).

No campo histórico, o cenário milanês do século IV marcado pelo neoplatonismo cristão influenciou Agostinho a reportar-se às Escrituras. Na questão filosófica, a possibilidade de conceber Deus como um ser espiritual, não corpóreo, e o mal como privação, diferentemente do que apregoava o maniqueísmo, quiçá tenha impulsionado o Hiponense a reler as Escrituras.

Sob a moção neoplatônica, Agostinho pode compreender que os elementos inteligíveis são superiores aos elementos visíveis e sensíveis:

\begin{abstract}
Mas como és louvado também nos céus, ó Deus, que te louvem todos os teus anjos nas alturas, todas as potestades, o sol e a lua, todas as estrelas, a luz, o céu dos céus e as águas que estão acima do firmamento, louvem todo o teu nome. Eu já não podia desejar nada melhor, pois, refletindo de modo mais sensato a respeito disso tudo, compreendia que se as criaturas superiores são melhores que as inferiores, o conjunto de todas elas é ainda melhor (AGOSTINHO, 1984, p. 178).
\end{abstract}

Em posse dessa percepção, o Hiponense concebe que, possivelmente, a Verdade, que se encontra na realidade inteligível, seria estável, imutável e comum a todos. Sendo mister para contemplá-la a ascensão do físico e sensível para o metafísico e intelectivo. Desse modo, "a leitura agostiniana dos livros platônicos fez uma coisa que todos puderam compreender: levou Agostinho a uma conversão final e definitiva de uma carreira literária para uma vida na Filosofia" (BROWN, 2005, p. 123).

Na leitura e reflexão dos livros neoplatônicos, Agostinho obtém uma chave interpretativa que o possibilita resolver duas questões pontuais: Deus como substância espiritual e o mal como não-ser. Resolvendo tais questões, Agostinho vence dois grandes questionamentos que o atormentavam.

\title{
A consecução de um ideal: 0 ócio filosófico
}

Para a realização desse intento, o diálogo com o presbítero Simpliciano (Cf. AGOSTINHO, 2002, p. 167-176), confessor de Ambrósio, em 386 d. C., foi de suma 
importância. Simpliciano congratulou-se com Agostinho pela leitura neoplatônica que fizera, recomendando-Ihe também a leitura do epistolário paulino.

Simpliciano contou sobre a experiência religiosa de Antão, que ao deixar suas atribuições familiares e profissionais, buscou numa vida ermitã a Sabedoria. Teria sido esse fato e as indicações de Simpliciano, corolários desse colóquio, que fizeram com que o Hiponense decidisse abandonar seu ofício da cátedra de retórica e se refugiar com os seus amigos em Cassicíaco?

A cena em que Agostinho retrata sua conversão é mister para entender essa atitude de Agostinho:

Assim falava e chorava, oprimido pela mais amarga dor do coração. Ei que, de repente, ouço uma voz vinda da casa vizinha. Parecia um menino ou menina repetindo continuamente uma canção: Toma e lê, toma e lê. Mudei de semblante e comecei com a máxima atenção a observar se se tratava de alguma cantilena que as crianças gostam de repetir em seus jogos. Não me lembrava, porém, de têla ouvido antes. Reprimi o pranto e levantei-me. A única interpretação possível, para mim, era a de uma ordem divina para abrir o livro e ler as primeiras páginas que encontrasse. Tinha ouvido que Antão, assistindo por acaso a uma leitura evangélica, sentiu um chamado, como se a passagem lida fosse pessoalmente dirigida a ele: Vai, vende os teus bens e dá aos pobres, e terás um tesouro nos céus. Depois, vem e segue-me. E logo, através dessa mensagem converteu-se a ti. Apressado, voltei ao lugar onde Alípio ficara sentado, pois, ao levantar-me, havia deixado aí o livro do Apóstolo. Peguei-o, abri e li em silêncio o primeiro capítulo sobre - qual caiu o meu olhar: Não em orgias e bebedeiras, nem devassidão e libertinagem, nem nas rixas e ciùmes. Mas revesti-vos do Senhor Jesus Cristo e não procureis satisfazer os desejos da carne. Não quis ler mais, nem era necessário. Mal terminara a leitura dessa frase, dissiparam-se em mim todas as trevas da dúvida, como se penetrasse no meu coração uma luz de certeza (AGOSTINHO, 1984, p. 214-215, grifos do autor).

O respectivo episódio apresenta uma profunda angústia que atormentava o Hiponense. Contudo, a partir da leitura que fizera de um excerto da carta paulina à comunidade de Roma, Agostinho, de forma corajosa e decidida, por meio do ajudo da Graça divina, resolve, a partir daquele momento, abandonar seu ofício profissional e seguir, durante o período em Cassicíaco, um estilo de vida semelhante ao de Antão. Não com a mesma radicalidade, porém com o mesmo ideal de 
contemplar a Verdade, que ele pressupunha ser possível encontrar no âmago de seus pensamentos e longe da perturbação citadina.

Brown apresenta o possível motivo da opção de Agostinho por um itinerário semelhante, mas díspar do de Antão:

A vida de Agostinho na 'Filosofia' foi perpassada por São Paulo, mas ainda poderia ser transmitida em termos clássicos. As mais altas recompensas de uma vida desse tipo estavam reservadas, quase que automaticamente, àqueles que haviam recebido uma formação clássica tradicional. Essa noção de continuidade é ainda mais surpreendente na medida em que Agostinho já ouvira falar de uma alternativa de vida clássica na 'Filosofia': a dos monges do Egito. $O$ ascetismo desses homens envolvera muita mortificação puramente física e uma ruptura decisiva com as formas da cultura clássica. Mas o exemplo de Santo Antônio havia deixado intacto o projeto intelectual de Agostinho. Ele tencionava continuar a ser um homem culto: como escreveu a Zenóbio, alguns homens lidavam com as feridas que lhes eram infligidas pelos sentidos 'cauterizando-as na solidão', enquanto outros 'Ihes aplicavam unguento' por meio das artes liberais. Fica patente que Agostinho, cercado por parentes e amigos e com sua biblioteca em Cassicíaco bem suprida de livros tradicionais, optou pela abordagem mais delicada das artes liberais (BROWN, 2005, p. 135).

O itinerário adotado por Agostinho, deste modo, vai ao encontro do que ele advogava na $\operatorname{Ordem}^{7}$ (Cf. AGOSTINHO, 2008, p. 222-224; 234-245) e Solilóquios ${ }^{8}$ (Cf. AGOSTINHO, 1993, p. 48-50; 89-92). O Hiponense, nessas obras, defendia que o caminho para a Verdade consistia obrigatoriamente na vivência da disciplina ética e no estudo das disciplinas liberais. Ou seja, uma conduta de vida regrada que possibilite o foco integral na busca da Verdade, que é possível através da dedicação e aperfeiçoamento do homem nas artes liberais.

O projeto filosófico de Agostinho, ensejado no retiro de Cassicíaco (Cf. BENTO apud AGOSTINHO, 2008, p. 10), por volta de setembro de 386 d. C. à março de 387 d. C., fora motivado pelo seu desejo de refugiar-se da agitação urbana. Esse ideal de liberdade criativa e intelectiva era o anseio dos amigos do Hiponense:

\footnotetext{
7 Numa certa madrugada, Agostinho, Licêncio e Trigécio principiam uma discussão sobre a ordem pela qual a Providência governava tudo o que existia (Cf. AGOSTINHO, 2008, p. 164-165).

8 É também deste período os Solilóquios, que possivelmente foi redigido no final de 386 ou início de 387. Nesta obra Agostinho indaga-se a si, questionando a Razão com o intento de refletir sobre os elementos fundamentais para almejar a sabedoria e se debruçar filosoficamente sobre Deus e a alma (Cf. OLIVEIRA apud AGOSTINHO, 1993, p. 7-13).
} 
Éramos muitos os amigos que, sentindo aversão pelos aborrecimentos e tumulto da vida social, tínhamos discutido, projetado, e já quase decidido, retirarmo-nos para vivermos em meditação longe do mundo dos homens. Tínhamos organizado o nosso retiro, de modo a colocar em comum todos os bens que possuíamos, formando assim um patrimônio único (AGOSTINHO, 1984, p. 153).

Para esse fim, Agostinho escolhe familiares e amigos. Perante tal eleição, Brown faz a seguinte reflexão:

Agostinho havia reunido um grupo heterogêneo para uma vida de otium filosófico: uma senhora devota, dois primos sem instrução e dois alunos particulares, ambos com cerca de 16 anos. Os diálogos que emergem desse grupo mostram com muita clareza um dos principais dons de Agostinho como artista: a capacidade instintiva de criar uma forma nova e interessante a partir dos materiais mais improváveis. Foi um golpe magistral de espetáculo literário transformar esse estranho grupo em veículo perfeitamente apto a transmitir um ideal de filosofia pelo e para o amador. É que a 'verdadeira Filosofia' agostiniana era também a religião de uma Igreja universal. Por conseguinte, precisava ser ampliada para acolher toda sorte de mentalidades: era preciso criar uma espécie de viabilização universal do saber. $\mathrm{E}$ o círculo de Agostinho foi escolhido a dedo para transmitir exatamente essa mensagem - a de que o 'mais alto cume' da sabedoria estava ao alcance de qualquer mente moderadamente instruída e séria $(2005$, p. 145146, grifos do autor).

Segundo o excerto acima, é possível refletir que tal itinerário filosófico, realizado por Agostinho e seus amigos, sob a relação dialógica da Autoridade e da Razão, é uma trilha que todas as pessoas podem também realizar.

Com efeito, a estadia em Cassicíaco para filosofar, leva a termo o propósito despertado em Agostinho por intermédio da leitura de Hortênsio, pois a leitura desse diálogo colocara na mente do Hiponense o afã de se dedicar totalmente à vida intelectual. Para isso, Agostinho deveria abandonar o poder e o prazer para dedicar-se, de preferência, a uma espécie de comunidade monástica de espíritos afinados, tendo em vista a busca da verdade (Cf. KIRWAN, 1989, p. 3).

Portanto, essa busca é parte integrante e fundamental na vida do Hiponense, porque "quando Agostinho recolheu-se a Cassicíaco, em setembro de 386, parecia estar seguindo uma tradição veneranda e encantadora: livre das preocupações de 
uma carreira pública, estava prestes a ingressar numa vida de ócio criativo, dedicada a uma vocação séria" (Cf. BROWN, 2005, p. 141).

A experiência em Cassicíaco fez com que Agostinho redescobrisse o encanto inicial pela Filosofia:

Quando Agostinho se recolheu a Cassicíaco, já tinha havido nele uma mudança nesse nível profundo. Por causa dessa mudança, ele tornou a se sentir livre, apto a ir em busca de seus interesses com energia e segurança renovada [...]. A criatividade súbita e otimista da nova vida agostiniana 'na Filosofia' espelhou os sentimentos de um homem que, por alguns anos preciosos, pôde enfim sentir que havia recuperado a inocência perdida (BROWN, 2005, p. 136).

Nas Confissões, o Hiponense retrata a sua ida para Cassicíaco desta forma:

Chegou o dia de libertação material da profissão de retórico, da qual eu já estava espiritualmente livre. E aconteceu que me livraste a língua de uma atividade da qual já me havias livrado o espírito. E, partindo para a casa de campo com todos os meus, eu te louvava com alegria (AGOSTINHO, 1984, p. 224).

Em Cassicíaco, Agostinho, juntamente com seus amigos e familiares, dedicase ao ócio filosófico (Cf. AGOSTINHO, 2008, p. 10.72). Nele Agostinho dedica-se primeiramente a discutir a possibilidade do conhecimento. Perante essa iniciativa do Hiponense é possível fazermos a seguinte pergunta: o que o move a se voltar primeiramente sobre a questão da possibilidade do conhecimento, no primeiro diálogo em Cassicíaco, se, conforme vimos, em posse da abordagem alegórica das Escrituras, Agostinho havia recuperado a confiança na Autoridade dessa e na descoberta da filosofia neoplatônica conseguia resolver a questão de Deus como ser espiritual e do mal como uma privação?

Decerto, a sua motivação foi o seu desejo de refutar os argumentos epistemológicos acadêmicos, conforme ele mesmo reafirma em sua obra Retratações:

Depois de ter abandonado ou o que havia conseguido ou o que ambicionava conseguir no tocante às vaidades deste mundo, ainda não batizado, e me tivesse entregado ao ócio da vida cristã, escrevi primeiramente Contra os Acadêmicos ou sobre os acadêmicos, com a finalidade de afastar de meu espírito seus argumentos com maior número possível de razões, pois também a mim me preocupavam esses argumentos, pois levam muitos à falta de esperança de encontrar a verdade e proíbem a qualquer um de assentir à 
verdade, e ao sábio, de acolher algo como manifesto e evidente, visto que tudo lhes parece obscuro e incerto. Isso foi feito graças à misericórdia e à ajuda do Senhor (Cf. AGOSTINHO, 2020, p. 10, grifos nossos).

Percebe-se, seguindo agora o parecer agostiniano das Retratações, que a redação do Contra os Acadêmicos foi salutar para que o Hiponense pudesse reafirmar a si e a seus amigos que o homem pode contemplar a Verdade.

Nesse sentido, a finalidade de almejar a Verdade por intermédio da filosofia impulsionou Agostinho, juntamente com seus amigos, a empreender um debate filosófico sobre a possibilidade do conhecimento:

Uma coisa era certa: Agostinho podia renunciar à postura cética da Nova Academia. O primeiro livro que escreveu em seu 'retiro' filosófico em Cassicíaco voltou-se contra esse ceticismo. Ao declarar desse modo que era possível encontrar uma 'filosofia verdadeira', é bem possível que Agostinho tenha se dirigido contra tal ceticismo (BROWN, 2005, p. 124).

Destarte, o primeiro diálogo filosófico ocorrido entre Agostinho e seus amigos é intitulado Contra os Acadêmicos. Nesse diálogo o fito é o de contrapor a posição cética acadêmica apresentada por Cícero na sua obra Acadêmicas, a qual conhecia bem. Assim, o Hiponense envida seus esforços na confrontação da posição cética da Média e Nova Academia, porque ele objetava tirar de si qualquer resquício do seu outrora período cético, bem como afugentar essa barreira dos seus:

Quanto ao essencial, a refutação agostiniana do ceticismo está contida no Contra os Acadêmicos. $\mathrm{O}$ escrito resume as conversas entre Agostinho e seus amigos na vila de Cassicíaco, imediatamente após sua conversão. Já é notável que a refutação do ceticismo tenha sido a primeira ocupação do novo cristão. 0 desespero de encontrar a verdade, que ele acabava de vencer em si mesmo, é também o primeiro inimigo que ele quer vencer nos outros. Enfim, Agostinho tinha certezas, portanto a certeza era possível. Ao salvar o pensamento do desespero, o Contra os Acadêmicos desobstruía o seio da filosofia e abria a sua porta (GILSON, 2006, p. 84, grifos do autor).

Aliás, tal intento é de máxima urgência para Agostinho, pois este dedicou o Contra os Acadêmicos, o primeiro livro de uma série de diálogos filosóficos escritos de 386 d. C. a 387 d. C., para criticar a posição cética da Academia e defender a 
possibilidade de o homem almejar o conhecimento (Cf. DALY apud STUMP; KRETZMANN, 2006, p. 159).

Tal propósito agostiniano de refutação da postura cética acadêmica evidencia o seu anseio de contemplar a Verdade, buscando desanuviar as trevas da incerteza, para que se possa, fundamentado na Autoridade e reforçado pela Razão, ter a possibilidade de almejar a Verdade.

\section{Considerações finais}

A reflexão sobre tal percurso traçado pelo Hiponense pode levantar a respectiva questão: é possível que o itinerário filosófico agostiniano, tendo o afã de contemplar a Verdade, possa ser uma caminhada realizada por todas as pessoas ou é simplesmente uma empreita subjetiva e de matizes próprias ao Hiponense? Decerto, a resposta possa ser que os passos concedidos por Agostinho elucidam somente sua trilha existencial e não se possa concebê-la como um mapa obrigatório para todos. Por outro lado, as bases da caminhada filosófica agostiniana, Autoridade e Razão, podem consistir nos arrimos de todas as pegadas filosóficas empreendidas pelo homem. Pois, sem o assentimento às informações perpassadas pela família e pelos amigos não se pode obter o mínimo necessário para um maior e melhor autoconhecimento. Ademais, a recusa de todas as teses propugnadas pelos filósofos e intelectuais de outro ramo do conhecimento humano impossibilita a obtenção do necessário substrato intelectual para se proceder uma investigação sobre o mundo. Assim, é razoável inferir que a Autoridade pode preceder e auxiliar a Razão para todo e qualquer empreendimento filosófico. Logo, Autoridade e Razão podem constituir as bases para a trilha filosófica.

\section{Referências}

ABBAGNANO, Nicola. Dicionário de filosofia. Tradução de Alfredo Bosi e Ivone Castilho Benedetti. 5. ed. São Paulo: Martins Fontes, 2007.

AGOSTINHO, Santo. Confissões. Tradução de Maria Luiza Jardim Amarante. 3. ed. São Paulo: Paulinas, 1984. 
AGOSTINHO, Santo. Contra acadêmicos; $A$ ordem; $A$ grandeza da alma; $O$ mestre. Tradução de Agostinho Belmonte. Paulo: Paulus, 2008.

AGOSTINHO, Santo. O livre arbítrio. Tradução de Nair de Assis Oliveira. São Paulo: Paulinas, 1995.

AGOSTINHO, Santo. Retratações. Tradução e notas de Augustinho Belmonte. São Paulo: Paulus, 2020.

AGOSTINHO, Santo. Solilóquios; Vida feliz. Tradução de Nair de Assis Oliveira. São Paulo: Paulinas, 1998.

AUGUSTINE'S, St. Confessiones. Translation by William Watts. In Two Volumes. Volume I London/New York: William Heinemann/ The Macmillan CO. 1912.

AUGUSTINE'S, St. Confessiones. Translation by William Watts. In Two Volumes. Volume II London/New York: William Heinemann/ The Macmillan CO. 1912.

BROWN, Peter. Santo Agostinho: uma biografia. Tradução de Vera Ribeiro. 2. ed. Rio de Janeiro: Record, 2005.

CíCERO, Marco Túlio. Acadêmicas. Tradução de José Rodrigues Seabra Filho. Belo Horizonte: Nova Acrópole, 2012.

DUTTON, Blake D. Augustine and academic skepticism: a philosophical study. New York: Cornell University Express, 2016.

GILSON, Etienne. Introdução ao estudo de Santo Agostinho. Tradução de Cristiane Negreiros Abbud Ayoub. SãoPaulo: Discurso Editorial/Paulus, 2006.

HENRY, Paul. Plotin et L' occident. Firmicus Maternus, Marius Victorinus, Saint Augustin et Macrobe. Louvain: Spicilegium Sacrum Lovaniense Bureaus, 1934.

KENNY, Anthony. New history of western philosophy. medieval philosophy Volume II. Claredon: Oxford University Press, 2005.

KIRWAN, Christopher. Augustine: the argument philosophers. London and New York: Routledge, 1989.

MATTHEWS, Gareth B. Santo Agostinho: a vida e as ideias de um filósofo adiante de seu tempo. Tradução de Álvaro Cabral: Rio de Janeiro: Zahar, 2007.

MENN, Stephen. Descartes and Augustine. Cambridge: Cambridge University Press, 1998.

STUMP, Eleonore; KRETZMANN, Norman (orgs.). Cambridge company to Augustine. Cambridge: Cambridge University Press, 2001.

TESKE, Roland J. Augustine of Hippo: philosopher, exegete, and theologian. Milwaukee: Marquette University Press, 2009. 
RECEBIDO: 30/06/2020

RECEIVED: 30/06/2020

APROVADO: 26/05/2021

APPROVED: 26/05/2021 